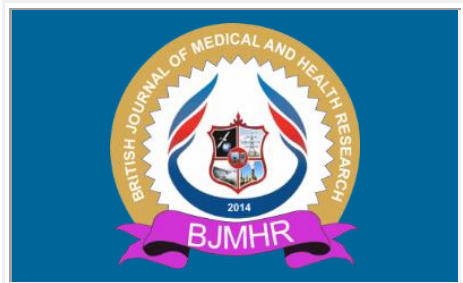

\title{
BJMHR
}

British Journal of Medical and Health Research

Journal home page: www.bjmhr.com

\section{Clinical picture of Covid 19 in Indian Children, Rarity of Covid Toes or Hands}

\section{Phadke $\mathbf{M}^{1 *}$, Menon $\mathbf{P}^{2}$, Ambike $\mathrm{D}^{3}$, Deshpande $\mathrm{A}^{4}$, Nair $\mathbf{R}^{\mathbf{5}}$, Saunik $\mathrm{S}^{\mathbf{6}}$}

1.Sr. Adv. Govt, UNICEF, Mumbai, India.

2. Department of Paediatrics $\mid$ Dr DY Patil Medical College, Pune, India

3.Prof , of Ped, PCMC, SPGI, Yashwantrao Chavan Memorial Hospital, Pune, India.

4.Nutrition Officer, UNICEF, Mumbai, India,

5.Nutrition Specialist, UNICEF, Mumbai, India.

6.Addl. C. S. Govt. of Mah, Mumbai, India

\section{ABSTRACT}

The incidence of Covid 19 affecting children and young adults has been around 1 to $2 \%$ of total cases. Vast majority of pediatric cases have probably been mild or asymptomatic. However, there are a group of children who present with serious symptoms requiring hospitalization. We herewith describe Indian experience and varied clinical manifestations of published and unpublished pediatric Covid 19 cases. Majority of the clinical presentations are similar to reported series with few stark differences.

Keywords: Covid 19, clinical presentations 


\section{INTRODUCTION}

For the purpose of this study, we collected published cases of Covid 19 in Indian children from

scientific medical journals, through Pubmed, Google scholar science direct etc...In addition some cases were published in Indian newspapers, some were gathered through personal communication and some was data on file. All the literature was reviewed and cases were compiled and analyzed. 
Table 1 Describes clinical picture of pediatric cases from India..

\begin{tabular}{|c|c|c|c|c|c|c|c|c|c|}
\hline Symptom & $\begin{array}{l}\text { Sarangi, } \\
\text { Et Al. (2) }\end{array}$ & $\begin{array}{l}\text { Mundlod, } \\
\text { Ambike et } \\
\text { al (3) }\end{array}$ & $\begin{array}{l}\text { Pathak } \\
\text { Jabalpur, }\end{array}$ & $\begin{array}{l}\text { Rao, Prabhu, } \\
\text { Bodhanwala } \\
\text { Wadia Mumbai } \\
\text { India(4) }\end{array}$ & $\begin{array}{l}\text { SOURAV } \\
\text { BANERJEE, } \\
\text { west Bengal } \\
\text { India 2020 }(5)\end{array}$ & $\begin{array}{l}\text { Sharmila } \\
\text { Ramteke } \\
(6)\end{array}$ & $\begin{array}{l}\text { Sagar } \\
\text { Lad } \\
\text {,data on } \\
\text { file }\end{array}$ & $\begin{array}{l}\text { Personal } \\
\text { communicati } \\
\text { on with } \\
\text { pediatricians }\end{array}$ & Total \\
\hline All cases & 178 & 158 & 45 & 123 & 41 & 30 & 50 & 150 & 775 \\
\hline Fever & 17 & 49 & 16 & 24 & 9 & 9 & & 105 & $229(29.5 \%)$ \\
\hline Cough & 8 & 21 & 10 & & 5 & 8 & & 15 & $67(8.6 \%)$ \\
\hline Sore throat & 7 & 3 & & & & & & & $10(1.3 \%)$ \\
\hline Breathlessness & & 6 & 8 & 25 & 5 & 3 & & 7 & $54(6.9 \%)$ \\
\hline Cold & 15 & 7 & & & & & & 10 & $32(4.1 \%)$ \\
\hline Myalgia & 4 & & & & & & & & $4(0.5 \%)$ \\
\hline Headache & 2 & 1 & & & & 1 & & & $4(0.5 \%)$ \\
\hline \multicolumn{10}{|l|}{ Anosmia, Ageusia- } \\
\hline Abdominal pain & & 4 & & 15 & & & & 3 & $22(2.8 \%)$ \\
\hline Nausea Vomiting & & 7 & 8 & & & & & 2 & $17(2.2 \%)$ \\
\hline Diarrhoea & 2 & 6 & & & & & & 3 & $11(1.4 \%)$ \\
\hline \multicolumn{10}{|l|}{ Lethargy } \\
\hline \multicolumn{10}{|l|}{ Hiccoughs } \\
\hline $\begin{array}{l}\text { Abdominal pain like } \\
\text { acute appendicitis, } \\
\text { perforation }\end{array}$ & & & & & & & & 3 & $3(0.4 \%)$ \\
\hline \multicolumn{10}{|l|}{$\begin{array}{l}\text { Surgical abdomen, } \\
\text { pancreatitis }\end{array}$} \\
\hline \multicolumn{10}{|l|}{ Cyanosis } \\
\hline Convulsions & & & 6 & 13 & & & & 1 & $20(2.5 \%)$ \\
\hline $\begin{array}{ll}\text { Viral encephalitis } \\
\text { picture }\end{array}$ & & & 2 & & & & & 1 & $3(0.4 \%)$ \\
\hline \multicolumn{10}{|l|}{ Conjunctivitis } \\
\hline Rash & & & & & & & & 1 & $1(0.1 \%)$ \\
\hline
\end{tabular}




\begin{tabular}{|c|c|c|c|c|c|}
\hline $\begin{array}{l}\text { TSS like Shock but no } \\
\text { organisms on culture }\end{array}$ & 4 & & & 1 & $6(0.7 \%)$ \\
\hline $\begin{array}{l}\text { Myocarditis, } \\
\text { pericarditis, arrhythmia }\end{array}$ & & & & 4 & $4(5.1 \%)$ \\
\hline Kawasaki like. & 1 & & & 1 & $2(0.2 \%)$ \\
\hline Respiratory failure & 4 & & & 4 & $8(1.0 \%)$ \\
\hline ARDS & 2 & & & & $2(0.2 \%)$ \\
\hline \multicolumn{6}{|l|}{ Renal failure } \\
\hline GBS & 1 & & & 2 & $3(0.3 \%)$ \\
\hline Optic neuritis & & & & 2 & $2(0.2 \%)$ \\
\hline MIS-C Or PIMS & & 11 & 11 & 3 & $25(3.2 \%)$ \\
\hline \multicolumn{6}{|l|}{ Covid toes } \\
\hline Asymptomatic & 23 & 27 & & 40 & $90(11.6 \%)$ \\
\hline Any other & & & & & 00 \\
\hline
\end{tabular}




\section{DISCUSSION}

Commonest symptom in Indian children as seen in Table 1 is fever in $29.5 \%$ cases while the same as reported by Jessica is $48-59 \%$. Sore throat and cold were in $5.4 \%$ cases in our data compared to $7-20 \%{ }^{1}$. Not unsurprisingly anosmia or aguesia is not a common presentation in both. Gastrointestinal symptoms were seen in both the groups.(6.8\% vs $7-10 \%)$

Data on hospitalized children show that MIS-C( multisystem inflammatory syndrome) is seen in $3.2 \%$ of cases. Similar findings are seen in the meta analysis in Jessica's report. MIS-C or pediatric multiple inflammatory syndrome (PIMS) was defined as fever, presence of inflammatory markers, multisystem involvement and temporal association with Covid19 as evidenced by presence of $\mathrm{IgG}$ antibodies in blood during hospital stay. This commonality of symptom complex, bio and inflammatory markers differentiates MIS-C from Kawasaki disease. Cardiac involvement, toxic shock like symptoms myocarditis, arteriolar dilation is seen in some of our cases of MIS-C.

Surprisingly no case of Covid toes or hands has been reported in our series. Covid toes and Covid hands have been described affecting children and adults in many countries. The emergence of the COVID-19 world-wide pandemic has been associated with a constellation of cutaneous features in children ${ }^{7}$. Among the unusual dermatologic presentations are the socalled COVID toes, inflammatory nodules of feet and toes, sometimes hands and fingers. These are cutaneous chilblain like or acral porneo like lesions. The skin over distal parts of feet, toes, hands becomes purple colored, violaceous, bumpy and sometimes developing into blister like structures. Many patients are RTPCR positive for Covid 19 or some show presence of antibodies. It could be an immune mediated phenomenon producing inflammation of cutaneous blood vessels, capillaries, arterioles. None of the patients reported from India have shown Covid toes or hands. As against that, involvement of larger blood vessels, arteriolar dilatation is seen in some patients with MIS-C resembling Kawasaki. Whether absence of Covid toes and hands is related to higher atmospheric temperatures, more sunlight, dark skin, less moisture, bare feet walking or is coincidental remains to be studied.

\section{REFERENCES}

1. Jessica H. Rubens, Nadine Peart Akindele, Megan M Tschudy, Anna C Sick-Samuels have very clearly elucidated clinical manifestations of Covid19 in children in their article in BMJ, $1^{\text {st }}$ March,2021,372.

2. Epidemiological And Clinical Characteristics Of COVID-19 In Indian Children Bhakti Sarangi, Venkat Sandeep Reddy, Jitendra S Oswal, Nandini Malshe, Ajinkya Patil, Manojit Chakraborty And Sanjay Lalwani, Indian Pediatrics 914 Volume 57 October 15,2020 
3. Clinical and demographic profile of pediatric COVID-19 in a tertiary care teaching Hospital_Suryakant Sayanna Mundlod, Deepali Abhijit Ambike, Sabahat Ahmed, Abhijeet Byale, Medical Journal of Dr D Y Patil Vidyapeeth, volume 14,issue 2, 134136,2021

4. Clinical Spectrum and Atypical Presentations of COVID-19 in Hospitalized Children in a Tertiary Care Hospital: Prospective Observational Study, Shweta Pathak, Monica Lazarus, Pawan Ghanghoriya. Pediatric Oncall Journal (Oct-Dec 2020) Volume 17, Issue 4: 109-115

5. Outcome of Children Admitted With SARSs-CoV-2 Infection: Experiences From a Pediatric Public Hospital, Sudha Rao 1, Vrushabh Gavali, Shakuntala S Prabhu ,Radhika Mathur, Larissa Robert Dabre , Sanjay B Prabhu , Minnie Bodhanwala, Indian Pediatr . 2021 Jan 11;

6. A Preliminary Report Of COVID-19, In Children In India Sourav Banerjee, Aritra Guha, Avishikta Das, Mousami Nandi And Rakesh Mondal. Indian Pediatrics 963 Volume 57October 15, 2020

7. Paediatric COVID-19: Milder Presentation-A Silver Lining in Dark Cloud, Sharmila Ramteke, MD, Rajesh Tikkas, MD, Manjusha Goel, MD ,Shipra Mandraha, MD and Jyotsna Shrivastava, MD. Journal of Tropical Pediatrics, 2020, 00, 1-5

8. Personal communication with pediatricians from Pune Maharashtra, Data on file Pediatric COVID Toes and Fingers Merav Koschitzky, , Ryan Rivera Oyola, Mary LeeWong, Brian. Abittan, and Nanette. Silverberg. Clin. Dermatol. 021 Jan14 doi: 10.1016/j.clindermatol.2020.12.016

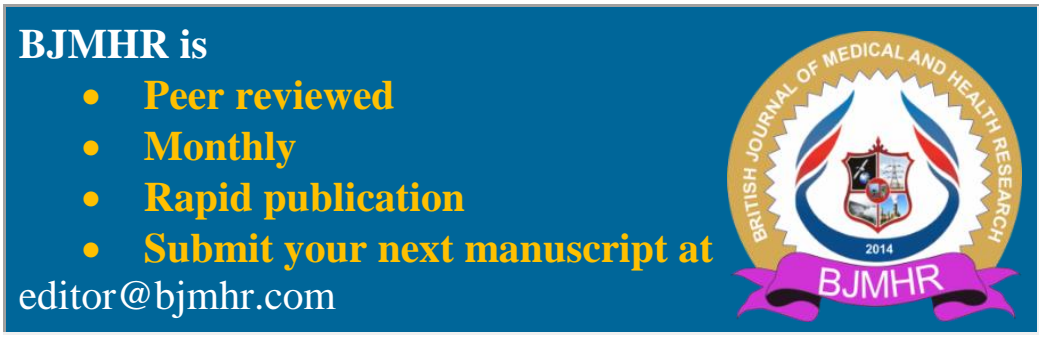

